\title{
The Sorry Steel: Trophy Guns in New Zealand's World War One Commemoration
}

\author{
PETER COOKE
}

\begin{abstract}
In relation to WWI war memorials, we traditionally we have had a picture of earnest committees raising funds to build an obelisk, and dedicating it in a ceremony filled with poignancy and regret, sorrow and pride. And while that is essentially correct, the picture Jock Philips and Chris McLean painted (in their 1990 book) was skewed in one salient aspect virtually all New Zealand communities also commemorated their fallen with a trophy gun. Hundreds of captured artillery pieces, mortars and machine guns were brought back from the front and distributed - to every city, town, borough, suburb and almost every school. This paper explores a slightly different view our commemorating the sacrifices of the Great War, one that added an element of 'cold steel' to the marble statuary. So what did we see in these trophy guns? Were they a triumphal statement or a reminder of loss? And what happened to them and the mode of commemoration they signified?
\end{abstract}

In relation to World War One war memorials a picture has traditionally arisen of earnest committees raising funds to build an obelisk or plant a tree, and dedicating it in a ceremony filled with poignancy and regret, sorrow and pride. And while that picture is essentially correct, it is skewed in one salient aspect - virtually every New Zealand community also commemorated their fallen with a trophy gun. Hundreds of captured artillery pieces, mortars and machine guns were brought back from the front and distributed - to every city, town, borough, suburb and very many schools. This paper explores a slightly different view of commemorating the sacrifices of the Great War, one that added an element of cold steel to the marble statuary. ${ }^{1}$

The concept of war trophies existed among pre-contact Maori, with a captured weapon conveying to its new owner any "mana" (eminence) formerly possessed by the vanquished. A captured warrior in possession of a weapon of significant mana would ask that his captors despatch him with that weapon, a request usually granted. ${ }^{2}$ In a Pakeha setting, cannon had a symbolic role. Cannon on display encouraged those present to marvel at the advance of technology, and this wow-factor extolled the prowess of the gun's owner -whether in the wharenui, the trading post or government house. ${ }^{3}$ Cannon were intended to induce a sense of awe and emotion, and were symbols of power. Firing salutes from ship or shore is an acknowledgement of that power. For example, salutes fired from Point Jerningham or North Head paid homage to visiting dignitaries or warships. Notable occasions continue to be marked with a salute: the 100 blanks fired on 4 August 2014 in Wellington commemorated the Great War in New Zealand's history. But earlier visitors, from Tasman to Cook and de Surville to D'Entrecasteaux, used their cannon to honour, impress or cower Maori whom they encountered. With the arrival of white settlers, the salute took hold. Amos Burr recalled a salute fired from the New Zealand Company ship Cuba in Wellington harbour in 1840 - for it blew his hands to pieces. ${ }^{4}$ More prosaically, guns were used for communication. With a signal gun a ship could to announce its presence, summon the pilot, passengers or lighters, or call for help.

Cannon were also part of death and mourning rituals. Cannon could be fired at tangi (funerals) of leaders: at Maketu the "loyal Arawas" in 1901 "fired salutes from the old cannons still in their possession.... No section of the Maoris were more devoted to our late Ruler [Queen Victoria] than the Arawas," and they complained that the Government would not provide gunpowder for such salutes. ${ }^{5}$ A silver-painted gun at Waiomio, the seat of Te Ruki Kawiti, was 
used at tangi for many decades. It was loaded with growing amounts of powder until on one occasion it shattered windows in a nearby marae building. ${ }^{6}$ Retired cannon also had a role in venerating the deceased by bearing them to their grave. Funerals are an important moment of public display, when the mana of the departed is indicated by the scale of pomp, and a gun carriage helped create that sense of importance. This was made clear immediately after World War One when many hundreds of veterans succumbed to their wounds, their weakened states or the influenza epidemic. Returned Soldiers' Associations asked for a gun carriage for military funerals, and Rotorua, for example, claimed that its 300 members and the patients of the large military hospital there deserved no less. With a dignified gun carriage and team of six, it "could turn out a decent military funeral worthy of a soldier of The Empire." ${ }^{7}$ But captured guns also played a large role in commemorating the losses incurred in achieving the victory of 1918.

\section{Trophy Gun Tradition}

Before World War One a tradition existed in New Zealand of guns marking battles and sacrifices. A carronade stood sentinel over Ruapekapeka pa in Northland, site of a battle in 1846. It was broken in that battle and could be interpreted by both sides in a way appropriate to their memories of or conclusions about its outcome. In Tauranga, after the Borough Council gained control of Monmouth Redoubt from the Permanent Force in the 1890s, it decided old guns had a heritage role in interpreting the old fort and the war during which it was built. ${ }^{8}$ The surrounding grounds, according to the Bay of Plenty Times, were "cleared of the dilapidated stables... and the Redoubt repaired and the old guns obtained free of cost, to restore it to something like its old appearance." A handful of other sites also displayed old guns to mark the period of colonial expansion, but some of those pieces had a role in trade as well as fighting. Blenkinsopp's cannon in Marlborough is in this category, because for decades it was thought of as the gun that bought the Wairau plains. ${ }^{10}$ If one accepts that the Wairau incident was the first battle in New Zealand Wars, then the gun also brought three decades of fighting.

Of greater poignancy to settlers were guns that marked our external wars. New Zealand's first was the Crimean War in the 1850s. Though the young colony sent no troops it contributed funds and like its Australian siblings received two trophy guns in return. They were Russian garrison 18-pounder smoothbores taken in the siege of Sebastopol, and they arrived in 1859. ${ }^{11}$ With the outbreak of war in New Zealand the following year they sat in Auckland's Fort Britomart for the next two decades, but in 1882 were monumentalized in Auckland's Albert Park. ${ }^{12}$ The park had been created from the Albert Barracks and included a grassy knoll with a flagstaff around which cannon would be positioned. The two Russian guns were joined by a French bronze 8-pounder field gun that was labelled "Waterloo." Though it is very unlikely to have been at the battle of Waterloo, it allowed people to recall that pivotal battle and reflect on how free from major wars Europe had been in its wake ${ }^{13}$. There were probably a number of Waterloo veterans in New Zealand, but certainly Crimean veterans lived here in numbers (one, Capt Joseph Hyde, lived in Wellington until 1926). ${ }^{14}$ By the 1890s these three trophies were joined by two 12-pounder Armstrong Rifled Breech Loaders, which were later mistakenly thought of as South African War trophy guns. A troopers' monument was built nearby, dedicated to the "New Zealand Battery Royal Artillery," reinforcing the link between display gun and commemoration. A handful of pom-pom and field guns did come to New Zealand from the Cape, and some graced parliament's front steps until they were all distributed to New Plymouth, Wanganui, Christchurch and Dunedin. ${ }^{15}$

\section{Lamentable Sound}

Even melted-down guns had an emotional pull - as demonstrated by church bells given in 1874 to a German Protestant congregation in Christchurch. As a strong statement of German nationalism after the Franco-German War, Chancellor Otto von Bismarck had captured French 
cannon melted down and presented bells made from the bronze to several German communities around the world. As a local paper predicted "the pealing of these bells will not fall pleasantly on the ears of Frenchmen," following their recent humiliation. ${ }^{16}$ During World War One the French Consul in New Zealand, Monsieur Hippeau, said the bells were "sad remains of Prussian militarism" and "continue to sully the soil of a friendly nation...." They reminded Frenchmen of the "deep wound" from "that sorrowful period of our history." 17 But he also admitted that since the "brilliant victories of the [French] Republican armies... of the Marne [in 1914] these bells have done nothing but lamentably sound... a remembrance odious to all Frenchmen," implying that German worshippers got solace from hearing them. ${ }^{18}$ The Government agreed and had the bells seized; they were melted down in $1918 .{ }^{19}$

\section{The Battlefields Cleared}

During and after the Great War, several hundred captured field guns, trench mortars and 1500 machine guns were brought back as war booty, trophies taken from the enemy. A clamour for them developed. Towns started talking of getting "their share" of the allocation. ${ }^{20}$ The new mayor of Gisborne was told to "make it his business to see that Gisborne gets a share of these" war trophies. ${ }^{21}$ Museums in Auckland, Christchurch and Dunedin "challenge[d] the right of the Government to concentrate all war trophies in the national collection at Wellington." 22 The Te Aroha Chamber of Commerce reflected many other local bodies when it asked "What has Te Aroha not done that it should be passed over in the distribution of war trophies?" 23 In some cases this was to satiate a need in suffering communities for instant commemoration. This need was reflected in comments made when trophies were received or unveiled: "it is a duty incumbent upon us [the Poverty Bay Herald said] to see that ... [our boys'] glorious achievements, their daring exploits and self-sacrificing acts are kept in remembrance." ${ }^{24}$ These trophy guns developed a new role as war memorials in their own right, if sometimes only briefly. Some committees established to fundraise and prepare for the permanent war memorial also received their allocated war trophy (Buckland and Ngatimoti are examples). When some guns in Auckland were later scrapped, the Auckland Star fumed that they had been "a reminder of the gallant sacrifices that were made by the N.Z.E.F." ${ }^{25}$ But before we can understand how they were used as memorials we need to first understand how they were collected and distributed.

As early as 1917 the allies gave thought to collecting war trophies, and Britain established the Imperial War Museum to hold them. ${ }^{26}$ New Zealand naturally thought it would follow suit with a New Zealand War Museum as a memorial and a storehouse to preserve the records and mementos of the war. The business of collecting trophies got into gear. The New Zealand War Records Section coordinated the trophy-gathering. It organised exhibitions of New Zealand trophies in Alexandria and London to show off the prowess of New Zealand Expeditionary Force and the very good reputation the New Zealand Division had earned on the battlefield. Exhibiting captured trophies was to "commemorate New Zealand's share in the present war," including the casualties. ${ }^{27}$ Australia and Canada held similar events, raising significant sums of money. ${ }^{28}$

Though Britain insisted the Imperial War Museum had first call on any collected trophy, it acknowledged the rightful claim to them by allied regiments. New Zealand sent men from 30 regiments overseas, and the towns in which those regiments were headquartered were told to expect a significant trophy. ${ }^{29}$ This applied to every major town in the country. Troops were encouraged to go out and claim trophies. "[T]he stuff we have," the Records Section said, "will be very precious." 30 Some were "the only material evidence to show that this battle was really a victory and not a defeat." 31 In all, 50 pieces of trophy artillery and mortars came from Egypt, the rest from Western Front battlefields. After about 60 had been sent from London on returning troopships, a second round of issues was made in 1919. These came from "Pool 2," 
the vast quantities of enemy material which were by then being cleared from battlefields and handed over by the defeated Central Powers. Most of these had little or no connection with the units of the New Zealand Expeditionary Force; they were issued wholesale and without prior claim. $^{32}$

Before leaving the United Kingdom, New Zealand Expeditionary Force made gifts of trophy cannon to towns in which its rear depots had been based. These included Walton-onThames, which hosted No.2 New Zealand General Hospital, Torquay for the New Zealand Expeditionary Force Discharge Depot, and the city of Stafford for the New Zealand Rifle Brigade camp nearby at Brocton. The gifts were to thank the towns for their hospitality and, in the case of the hospital, "in MEMORY of their OLD COMRADES who lie in the CHURCHYARD nearby." 33

In Wellington, a War Museum Committee was established in 1919 to receive trophies for the national museum and distribute others to towns. When the drive for a central war museum fell apart in the post-war malaise and depression, more trophies were available for regional distribution. The war museum's failure to get off the ground shifted the focus of commemoration to the hundreds of smaller towns, suburbs and cross-roads which now started to plan their own permanent war memorial and which in the interim strove to obtain a trophy gun. A machine gun or two were usually the first gun to arrive in any town.

\section{As Memorials}

The clamour from towns for a trophy was deafening, and most politicians supported it and immediately started lobbying for trophies. Mayors and their Council were urged to "hammer away' at the Government until they did get some." ${ }^{34}$ Auckland combined its desire for commemorating the war with an ambitious new museum project and sent a delegation to Wellington to lobby for funds and trophies. ${ }^{35}$ A special gallery for the display of war trophies was planned for the proposed new museum on Observatory Hill in the Domain.

Each of the 21 regimental recruiting territories formed a committee of local body leaders and senior officers to allocate guns to towns, and the members vied for the choicest or largest gun. The ten biggest cities in the Dominion were to expect a "siege" gun, or heavy piece. Up to five towns in each regimental district that hosted a sub-unit (such as company, squadron or battery headquarters), qualified for a significant war trophy - a field gun or howitzer. Infantry regiments seemed to get pre-eminence over mounted rifles, but then infantry regiments were much larger units. Returned Soldiers' Associations and officers' clubs, soldiers' clubs, and iwi perceived to be more "patriotic," might get a machine gun. Every school that wanted one received a machine gun. ${ }^{36}$

New Zealand's sense of egalitarianism would accept no other arrangement. If the mantra of Returned Soldiers' Associations - which started forming in all centres - was "equality of sacrifice," so was the notion of equal access to the spoils. It was "only fitting" said the Poverty Bay Herald, "that every community which has sent soldiers to the Great War should have some memento that can be handed on to future generations with pride. Our boys have been making history, and it is a duty incumbent upon us to see that their glorious achievements, their daring exploits and self-sacrificing acts are kept in remembrance." 37 The Auckland Museum delegation told the Prime Minister "The centres which had sent large numbers of soldiers to the war should have something to perpetuate the recollection of what their men had done." 38 An employee of the General Assembly Library in Wellington, 34-year-old Peter McColl, tried to send a trench mortar from France to the Minister of Internal Affairs, whom he knew. As well as its potential to earn funds if exhibited, McColl saw worth in it "as our boys lost their valuable lives in hundreds in the great battles across this locality." 39 
Many towns requested items for display. Civic leaders were keen not to miss out. Trophies were to be "placed in such positions as to ensure that they will remain a permanent memorial to those who captured them." 40 Wellington City Council chose to display the four machine guns which arrived by October 1918 in the Town Hall's first floor landing and the Newtown Museum. A few towns considered placing the guns in soldiers' cemeteries (such as that being planned at Karori) or arrayed alongside the many new war memorials being planned "in memory of the men who went to the front." 41 Travelling exhibitions of war trophies toured New Zealand in 1918. Napier City Council was prepared to spend $£ 100$ on freight (worth around $\$ 10,000$ now) if this helped them get a trophy direct from London. ${ }^{42}$

By the time the last troopships had returned, over 210 pieces of artillery and 130 trench mortars had arrived. The clamour for war trophies was so strong that 10 old guns once in service in New Zealand (15-pounders) were also made available to the War Trophies Committee for giving away to towns wanting a gun - and went to places like Takapau and Akaroa. Upon receipt, the local authority, Returned Soldiers' Association or war memorial committee then set about deciding where to display the gun, how to interpret it and whether to protect it from vandals or the weather. Many guns spent time in front of municipal buildings, until a park location was agreed. It was usually now that those opposed to trophy guns made themselves heard.

But to most townsfolk trophy guns were memorials to those who had died in the wars from which they were captured - and were displayed centrally. In many cases the permanent war memorial was then built alongside it. War memorials were built alongside trophy cannon at Arrowtown, Mt Roskill, Clyde, Cromwell, Dannevirke, Dunedin (The Oval), Hamilton (Soldiers Park), Martinborough, Naseby, Nelson (Queens Garden), Ngatimoti, Otautau, Roxburgh, Waiouru, Waipawa, Wanganui (Cooks Garden), and even on private land at Kuriheka, Maheno. In the 1930s two guns were added to the forecourt of the Auckland's War Memorial Museum - between the museum and cenotaph but, because this was deemed to be consecrated ground, were moved in the 1950s to in front of the cenotaph. Some towns felt they had an entitlement to a trophy. Waiapu for instance said it deserved a trophy because "it provided more men per head of population than any other district in New Zealand." 43 This was a common theme if a council felt its district had outdone its neighbours in any aspect. Names of the deceased appear not to have been listed on the gun or its signage, but many guns came with the name of the unit or formation that captured it, allowing relatives a link with their son's loss.

As the 1919 Peace Conference in Paris neared a conclusion, a number of towns started planning their peace celebrations for July. Some requested trophies be hurriedly issued or even loaned to them. The railway situation precluded despatch by land but local bodies that were prepared to pay for sea freight would be lent a trophy, on condition they return it to Wellington immediately afterwards. ${ }^{44}$ Few took advantage of this, for in general the peace parades were not displays of triumphalism, despite a few replica tanks and ships being paraded as fundraisers. ${ }^{45}$

After the flood of trophy arrivals turned into a trickle, the applications for them also tailed off (though it never died completely). ${ }^{46}$ As the glory of the war ebbed into a distressing memory, a sense of loss, people turned from warlike trophies to conceptual memorials that took their thoughts elsewhere - to more ethereal places. A raft of obelisks, statues, gateways and cairns were constructed over the next few years, to preserve for all time the names of their menfolk lost in the war (and in a few cases those who merely answered the call). ${ }^{47}$ 


\section{Triumphal?}

What did New Zealand see in trophy guns? When a trophy was proposed for New Plymouth after the Boer War, someone decried "captured [Boer] guns flaunting as trophies of their defeat and humiliation." 48 This was an objection to adding further woes to the defeated Boers, largely god-fearing rural farmers who were seen as very similar to New Zealand settlers. Similarly, when Auckland thought of asking a visiting Russian naval band to give a concert in Albert Park, "it was pointed out it would be extremely indelicate to get the Sclavs [sic] to play music near cannon captured from them." ${ }^{49}$ This was a minority view but it reflected an abhorrence for excessive triumphalism.

New Zealand's anti-militarist tradition - small but vocal - also opposed the concept of war trophies, but for a different reason. Members of the Passive Resisters' Union who unceremoniously tipped a Boer War pompom into the Avon River in Christchurch in 1912, were objecting to the militarization of New Zealand society, as they saw it, through the compulsory training scheme of the recent Defence Acts. Opposition to the display of trophy guns after World War One is a topic for further study. Some local body politicians (for example in Feilding and Hokitika) voiced objections to displaying items they saw as glorifying war. The Hokitika councillor suggested "a swamp at the back of the town, where the guns would not be an eyesore to the people." ${ }^{50}$ Opponents renewed their desire to rid towns of trophy guns in the 1920s and $30 \mathrm{~s}$. Together with the march of rust and rot, and the advent of formalised anti-war movements such as No More War, this led to a good number of trophy guns being scrapped or sold. ${ }^{51}$

But the scale of sacrifice from World War One, and its widely-spread nature, meant that few of these objections to commemorating the dead were successful. The Mayor of Wellington accepted the offer of a trophy from "the notable Gallipoli campaign" because it was "where our boys fought so bravely and so many of them died." trophy cannon in 1920, an opinion leader rejected any triumphalism in them and said that:

These trophies are engineering clarion calls to keen thinking and purposeful living... These will be welcomed by all, as being perpetual reminders of the greatest struggle in history, and of the unflinching efforts made to secure a lasting, honourable and progressive peace. ${ }^{53}$

When unveiling the trench mortar given to Nightcaps school in Southland, community leader Donald Sinclair said he hoped that school children "could take a lesson from the flag and gun before them.... Not that we wished to further humiliate a fallen foe, but to demonstrate that justice and freedom must always in the end prevail over tyranny and oppression." 54

In the trophy guns, some New Zealanders saw the prowess of its fighting forces. The weapons reflected a vigour, a virility and a propensity to prevail. An example comes from the reportage of a gun in Wellington, which was said to have been "captured from the Germans when the New Zealanders smashed through the Hindenburg Line." ${ }^{55}$ Other people also perhaps perceived a softer role, reflecting the sadness of war as seen from the point of view of victims, of women, of children. A piece of prose called 'German Guns - One Of Them Speaks' was published in Greymouth a month after that town received its two war trophy cannon:

I am a German field gun,... Many men come to look at me, and often children, but I cannot understand what they say. Some of the men are like those I saw broken on the battlefield; but they do not appear to be angry with me. I often see them smile with admiration and frequently the children sit on my shoulders and pat my neck! Perhaps they do not know my history. I wonder what they would do if they knew? ${ }^{56}$ 


\section{Emotional Landscape}

And finally, the sound of cannon-fire had a role in solemn commemoration, as recounted by the Auckland Star one Armistice Day:

One moment Queen Street was all movement and noise; the next it was as silent as a country road at midnight.... The sound of the signal gun from the Albert Park could be plainly heard all over the city.... Hats were lifted, smiles died out, chatter ceased, and in the lately throbbing street there was a hush that one could feel. Far more impressive to most people than even the solemnities of ANZAC Day, the two minutes' silence in memory of the gallant dead appeals to one as being the most effective mark of respect the living can pay.... The suddenly arrested traffic, the dramatic cessation of the city's roar, the bared heads of the men, the respectful attitude of the people standing just where they happened to be when they heard the signal boom - all conspire to wrench the thoughts from mercenary, worldly affairs, and carry them to the men that sleep the long sleep on foreign soil.... At the close of the silence,... came the second gun, and the busy city hummed once more. ${ }^{57}$

In conclusion, trophy guns on display have had a long role in New Zealand. They represented victories and allowed New Zealanders to marvel at technological prowess. In the years immediately after World War One they served as interim war memorials until permanent memorials were built, and helped people reflect on the momentousness of recent events.

\footnotetext{
${ }^{1}$ This topic is explored in full in Peter Cooke and Ian Maxwell, Great Guns - the Artillery Heritage of NZ (Defence of New Zealand Study Group, 2013).

2 Traditional Maori warfare is discussed in Elsdon Best, Notes on the Art of War, ed. Jeff Evans (Auckland: Reed, 2001); S Percy Smith, Maori Wars of the Nineteenth Century (Whitcombe \& Tombs, 1910); Elsdon Best, The Pa Maori (Dominion Museum/Te Papa, 1927/1995); and Angela Ballara, Taua - 'Musket Wars, 'Land Wars' or Tikanga? Warfare in Maori Society in the Early Nineteenth Century (Penguin, 2003).
}

3 Trevor Bentley documents cannon owned and displayed by Maori since the 1830 s, and mounted at trading stations, in Tribal Guns and Tribal Gunners (WillsonScott, 2013). For the guns displayed outside Parliament in the 1850s see Louis Ward, Early Wellington (Whitcombe \& Tombs, 1928), 415

${ }^{4}$ John A Knocks Papers, NZ Manuscripts, O91 N532 Vol 3, Alexander Turnbull Library; New Zealand Gazette and Wellington Spectator, 12 January 1842, 2; Wanganui Chronicle, 31 August 1876, 2; Evening Post, 21 May 1906, 4; Wairarapa Daily Times, 21 May 1906, 5.

5 Bay of Plenty Times, 6 February 1901, 2.

6 'Historic Cannon Fertile Valley', The Northlander, No.11, 1971, 6-7; 'Cannons I have Known', unpublished TS, Stuart Park, DOC Northland, 2008, 3

${ }^{7}$ Sec HA MacPherson, Rotorua RSA to MOD, 18 June 1919, "Headquarters Wellington: FuneralsMilitary-Veterans. Provision of Carriages, Uniforms \& Equipment." AYS8638, box755, AD1 15/184, Archives NZ. Emphasis as in original. 
${ }^{8}$ This was then called the second Maori War. Numbering the Queen's small wars was a very Victorian thing: those against the Chinese got to two (over opium), the Afghans three and the Ashanti in West Africa four.

${ }^{9}$ Bay of Plenty Times, 4 September 1905, 2.

${ }^{10}$ For instance Wellington Independent, 15 May 1866, 5.

${ }^{11}$ Southern Cross, 9 April 1859, 5.

${ }^{12}$ Hawke's Bay Herald, Volume 1, Issue 83, 23 April 1859, 2; Auckland Star, 24 August 1882, 3; ibid 30 August 1882, 2.

${ }^{13}$ Jan Morris, Pax Britannica (The Folio Society, 1992), Vol 3, 'Pax Britannica'; Gordon A Craig, Europe Since 1815 (Dryden Press, Alternate Edition, 1974)

${ }^{14}$ Bill Billett, "Australia's Trophies from the Crimean War", Sabretache, 38 (1997): 10-19; Auckland Star, 5 March 1881, 3; Jan Coates, Bluestone and Bureaucracy, A Project on the Presentation of Albert Barracks (Science and Research Internal Report No.65, Dept of Conservation, 1990): 35.

${ }^{15}$ Four large coast-defence guns were added to Albert Park in 1905, bringing to nine the number of weapons on display there. Wanganui Chronicle, 21 November 1905, 4. More small war trophies were added in 1918, presented in the 'flagstaff enclosure' in glass cabinets specially made for them. All were buried or removed during the Second World War.

${ }^{16}$ Grey River Argus, 28 January 1874, 2.

${ }^{17}$ Hippeau to MOD, 14 April 1917, "French Consul General: Auckland: Church Bells at Christchurch - Re being made in Germany from Guns Captured from the French in 1870 " AD1, box1043, $2^{\text {nd }}$ seq, $65 / 140$, Archives NZ. Fowler is believed to have been Hippeau's informant.

18 ibid.

${ }^{19}$ Evening Post, 6 August 1918, 8; "Christchurch City Council. Trophies - War - Re the Supply of", box $7632^{\text {nd }}$ seq, AD1 19/41/23, Archives NZ; Lyttelton Times, 6 March 1928.

${ }^{20}$ For instance, Auckland's Mayor. Auckland Star, 1 March 1921, 2

${ }^{21}$ Poverty Bay Herald, 1 May 1919, 2

${ }^{22}$ Grey River Argus, 1 February 1918, 3

${ }^{23}$ Bay of Plenty Times, 24 January 1919, 2

${ }^{24}$ Poverty Bay Herald, 1 May 1919, 2

${ }^{25}$ Auckland Star, 21 February 1933, Page 5

26 'First Annual Report of the Committee of the Imperial War Museum', April 1918; Evening Post, 26 August 1919, 3

27 Rhodes, 6 Sept 1918, "HQ NZEF: Writer Minister for Defence, NZ: Misc: Re Collection and Preservation of Trophies for NZ at end of war", XFE734 pt1, Archives NZ. 
${ }^{28}$ Evening Post, 26 August 1919, 3.

29 “War Trophies. The Method of Distribution”, Poverty Bay Herald, 12 May 1919, p8

${ }^{30}$ Rhodes to Colonel [George Hall, Assistant Quartermaster General, Administrative Headquarters, New Zealand Expeditionary Force], 1 Dec 1918, "HQ NZEF: Writer Minister for Defence, NZ: Misc: Re Collection and Preservation of Trophies for NZ at end of war", XFE734 pt1, Archives NZ.

${ }^{31}$ Stewart to NZEF Egypt, 13 Feb 1919, "HQ NZEF: Writer Minister for Defence, NZ: Misc: Re Collection and Preservation of Trophies for NZ at end of war", XFE734 pt1, Archives NZ.

${ }^{32}$ Peter Cooke and Ian Maxwell, Great Guns - the Artillery Heritage of NZ (Defence of New Zealand Study Group, 2013), Appendix 1, 423.

${ }^{33}$ NZEF to Mayor, 12 Sept 1919, “Trophies-Gun-Torquay-Presentation of”, WA1/1/3/17, 4/7, Archives NZ. Capitalising as in original.

${ }^{34}$ Poverty Bay Herald, 30 July 1919, 5.

${ }^{35}$ TF Cheeseman to AJ Entrican, 11 July 1919, "War Trophies-Gallipoli Trophies-2 ancient mortarsFlanders Trophies-3 Machine Guns", Acc275 box12 record 16-126, Auckland City Archives.

${ }^{36}$ The file 'Allocation of War Trophies', AD1 19/41/3 Pt1, Archives NZ, lists many schools that asked for and received a machine gun trophy. The number distributed to schools is unknown, but a few hundred schools are estimated to have received one, out of around 1500 machine gun trophies sent to NZ. Cooke \& Maxwell, Great Guns, 2013, 66.

${ }^{37}$ Poverty Bay Herald, 1 May 1919, 2.

${ }^{38}$ Poverty Bay Herald, 7 August 1919, 5.

${ }^{39}$ PH McColl to Minister of Internal Affairs, 11 July 1917, "Trophies from the Front-Re Presentation to NZ Government", AD 19/41, Archives NZ. There is no evidence this mortar was returned to NZ. McColl (1880-1956) had sailed as reinforcement for $2^{\text {nd }}$ Battalion NZ Rifle Brigade in June 1916, and returned home in 1919.

${ }^{40}$ WCC to NZMF, 7 Oct 1918, "Competitions and Trophies - Trophies - Presentation to Wellington City", AD1 19/41/7, Archives NZ.

${ }^{41}$ WCC to PM, 2 June 1920, "Competitions and Trophies - Trophies - Presentation to Wellington City", AD1 19/41/7, Archives NZ.

${ }^{42}$ Poverty Bay Herald, 24 January 1920, 6.

43 “Waiapu County Council”. Poverty Bay Herald, 6 August 1919, 4.

${ }^{44}$ Poverty Bay Herald, 15 July 1919, 5.

45 “Military Mockery", Tank TV-the Motor Vehicle at War, 27, December 2003, 4-6.

${ }^{46}$ In 1927 the Dept of Internal Affairs wrote to all councils who had received a trophy to see if they still wanted them. This was to meet ongoing demand. "Miscellaneous - War Trophies Distribution of - General file", IA1 158/24, ANZ 
${ }^{47}$ Chris McLean and Jock Phillips, The Sorrow \& the Pride - New Zealand War Memorials (Historical Branch, Dept of Internal Affairs, GP Books, 1990), says around 450 war memorials were erected after World War One.

${ }^{48}$ Taranaki Herald, 29 July 1902, 1.

${ }^{49}$ Taranaki Herald, 2 January 1889, 2.

${ }^{50}$ Grey River Argus, 13 July 1920, 3; Feilding Star, 12 November 1920, 2.

${ }^{51}$ This is discussed in Cooke and Maxwell, Great Guns, op cit, 71-85.

${ }^{52}$ The trophy was a trench mortar of Japanese manufacture offered by Lt Col Herbert Hart in 1917. The gun did not arrive because it was claimed by the Imperial War Museum. "An Historic Gun For Wellington", Grey River Argus, 6 August 1917, 4.

53 "War Trophies", Northern Advocate, 10 April 1920, 2.

${ }^{54}$ Otautau Standard and Wallace County Chronicle, 20 December 1921, 2.

${ }^{55}$ Evening Post, 4 May 1920, 6, in reference to the 13.5cm Krupp on Dixon St.

${ }^{56}$ Grey River Argus, 29 May 1920, 6.

57 "Hushed City. Tribute To The Dead. Another Armistice Day. Impressive Street Scene. The Eleventh Anniversary". Auckland Star, 11 November 1929, 8. 